DOI: $\underline{10.35619 / \text { iiu.v1i10.161 }}$

\author{
Козлюк Ольга \\ кандидат педагогічних наук, доцент, \\ доцент кафедри педагогіки і психології (дошкільної та корекційної) \\ імені проф. Т.І.Поніманської \\ Рівненського державного гуманітарного університету, \\ м. Рівне, Україна \\ ORCID: 0000-0002-6948-327X \\ e-mail: olga_rdgu@ukr.net
}

\title{
ВИХОВАННЯ ТОЛЕРАНТНОГО СТАВЛЕННЯ ДО ДОШКІЛЬНИКІВ З ОСОБЛИВИМИ ОСВІТНІМИ ПОТРЕБАМИ
}

\begin{abstract}
Анотація. У статті обгрунтовується актуальність виховання толерантного ставлення до дошкільників з особливими освітніми потребами в умовах інклюзивної освіти. Вказується на необхідність переоцінки поглядів і усталених стереотипів на дитину 3 особливими освітніми потребами та втілення інклюзивних цінностей в умовах освіти для сталого розвитку. Автор у статті виходить 3 позиції, що впровадження інклюзивної освіти сприяє соціалізації як звичайних дітей, так і дітей 3 особливими освітніми потребами. Оскільки вона сприяє формуванню у здорових дітей толерантності до фізичних і психічних недоліків однолітків, формуванню почуття взаємодопомоги і прагнення до взаємодії, а у дітей з особливими потребами спільне перебування веде до формування позитивного ставлення до своїх ровесників, адекватної соціальної поведінки, більш повного розкриття та реалізації потенціалу розвитку і навчання. Розкриваються особливості формування толерантного ставлення до дітей з особливими потребами в умовах групи інклюзивного закладу дошкільної освіти, шляхом реалізації основних педагогічних умов, серед яких: гуманізацію взаємин між дорослими та батьками; створення позитивного емоційного клімату взаємин дітей у колективі. Вказується на необхідність здійснення комплексного підходу до виховання толерантного ставлення: формування знань, розвиток та закріплення умінь толерантного ставлення до однолітків та їх перенесення у різні ситуації спілкування. Визначено перспективи подальших розвідок, які пов'язанні 3 подальшим пошуком ефективних методів і прийомів виховання дітей з особливими освітніми потребами.
\end{abstract}

Ключові слова: інклюзія, інклюзивні цінності, толерантне ставлення, виховання толерантного ставлення, дошкільники з особливими потребами.

Постановка проблеми. В умовах демократизації нашого суспільства поширення набули ідеї гуманізації завдань та змісту виховання дітей дошкільного віку. Відбулася переорієнтація філософської, психологічної та педагогічної науки 3 парадигми «суспільство - людина», головною метою якої було формування особистості за певними еталонами, нормами та підпорядкування власних інтересів державним, а основною ознакою була жорстка регламентація життєдіяльності дітей та організації освітнього процесу, на парадигму «людина - людство», яка передбачає орієнтацію на інтереси кожної особистості і задоволення її потреб.

Сучасна демократизація суспільних відносин пов'язана 3 визнанням нових орієнтирів виховання в теорії і практиці роботи закладів дошкільної освіти. Одним із таких орієнтирів, одночасно і пріоритетів сучасної дошкільної освіти, $є$ інклюзія, інклюзивне навчання. 3 огляду на це, необхідно здійснити переоцінку поглядів й усталених стереотипів на дитину, а конче на дитину 3 особливими освітніми потребами. Також потребує змін розвиток дошкільної освіти в напрямі гуманізації, що 
стосуються втілення інклюзивних цінностей (рівність усіх учасників освітнього процесі, права дитини, можливість повноцінної участі в усіх видах життєдіяльності закладу дошкільної освіти, підтримка відмінностей між дітьми, допомога кожному відчути себе частиною цілого та сприяння творчому розвитку дітей, відсутність насилля, толерантне ставлення, довіра, чесність, співчуття, оптимізм тощо) та створення інклюзивного освітнього простору.

В інструктивно-методичних рекомендації «Щодо організації діяльності закладів освіти, що забезпечують здобуття дошкільної освіти у 2019/2020 навчальному році (2019)» вказується на доцільність впровадження в роботу закладів дошкільної освіти технології формування в дошкільників соціально доцільної поведінки, у межах міжнародного суспільного руху - освіта для сталого розвитку.

Елементи стратегії Нової української школи такі, як: особистісно орієнтована модель навчання, розвиток критичного мислення у дітей, інтеграція освітніх напрямків та педагогіка партнерства повністю відповідають концепції сталого розвитку, яка грунтується на принципах педагогіки емпауерменту (надання людині мотивації й натхнення до дії), що передбачає нову, порівняно з традиційною, модель організації освітньої діяльності. Вона призначена не інформувати про предмет навчання, адже це не гарантує переходу від слів до дії, а формувати й автоматизувати навички чинити саме так, а не інакше. Інформація при цьому лише надихає того, хто вчиться, засвоює дію, яку він опановує (Міністерство освіти і науки України, 2019).

Для забезпечення сталого розвитку загальними завданнями дошкільної освіти $\epsilon$ створення умов для: формування у дітей початкових уявлень про дії та поведінку, що орієнтовані на сталий розвиток, необхідних для свідомого вибору способу власного життя; усвідомлення старшими дошкільниками необхідності збереження ресурсів Землі та особистої причетності до майбутнього суспільства і природи; розвиток у дітей звичок і моделей поведінки, що відповідають сталому розвитку бажання діяти у цьому напрямі (Міністерство освіти і науки України, 2019).

3 огляду на це, особливої актуальності набуває питання пошуку нових підходів до вирішення найважливішого завдання виховання - гуманного введення дитини в соціальне середовище, світ людей.

Аналіз останніх досліджень 3 проблеми. Останнім часом сутність теоретичних понять інклюзивної освіти достатньо повно викладена у працях Д. Гарнера, А. Дайсона, М. Кінг-Сірса, Д. Леско, П. Міттлера, М. Уілл. Зарубіжний досвід упровадження інклюзивної освіти систематизовано у працях Д. Бішопа, Х. Вулі, М. Дарсі， М. Емітейдж， Р. Зіглера， Д. Камерон， Д. Кларка， Н. Клегга， Б. Крауфа, Д. Попойнта, Д. Річлера, М. Фореста, Д. Фрайзена, Р. Хайкі. Вивченню окресленої проблеми у вітчизняному науковому просторі чимало приділяють увагу такі вчені, як: В. Ардзінба, Т. Бут, С. Колосов, А. Колупаєва, І. Мартиненко, І. Ломакова, М. Сварнік, В. Синьов, В. Ткачук, О. Ярська-Смірнова, М. Шеремет. Питанням створення інклюзивного середовища присвячені праці Т. Зубарєва, С. Кондратьєвої, Л. Олтаржевської та ін. Проблема формування міжособистісних стосунків в інклюзивних групах розглядається в дослідженнях Н. Бєлової, Ю. Ільїної. Проблеми соціального розвитку дітей дошкільного віку, виховання у них гуманного та толерантного ставлення до людей висвітлено у працях А. Богуш, Л. Варяниці, Н. Гавриш, І. Дичківської, Н. Кирсти, О. Козлюк, О. Кононко, С. Курінної, Т. Поніманської, І. Рогальської.

Мета статті: розкрити особливості виховання толерантного ставлення до дітей дошкільнят з особливими освітніми потребами.

Виклад основного матеріалу дослідження. Визначаючи суть спрямованості особистості, психолог С. Рубінштейн (2003, с. 26) зауважував, що серце людини все зіткане з ії ставлень до інших людей: те, чого вона варта, цілком визначається тим, яких стосунків вона прагне і як ставиться до інших людей. Наявна практика соціалізації дітей з різними освітніми потребами, пов'язаними з особливостями їхнього 
психофізичного розвитку, склалась у рамках медичної моделі, де вони переважно сприймаються як інваліди, і основна увага зосереджується на певному дефекті, ваді розвитку. Відповідно, це негативно позначається на формуванні у них соціального досвіду, оскільки орієнтує суспільство на виховання таких дітей у ізоляції, тобто в закладах закритого типу.

Водночас, упровадження інклюзивної освіти сприяє соціалізації як звичайних дітей, так і дітей з особливими освітніми потребами. Саме інклюзія в освіті сприяє формуванню у здорових дітей толерантності до фізичних і психічних недоліків однолітків, формуванню почуття взаємодопомоги і прагнення до взаємодії. У дітей $з$ особливими потребами спільне перебування веде до формування позитивного ставлення до своїх однолітків, адекватної соціальної поведінки, більш повного розкриття та реалізації потенціалу розвитку і навчання.

Серед важливих умов виховання толерантного ставлення до дошкільників 3 особливими освітніми потребами можна виокремити: гуманізацію взаємин між дорослими та дітьми та створення позитивного емоційного клімату взаємин дітей у колективі.

Система виховання толерантного ставлення до дітей 3 особливими освітніми потребами базується на особистісно орієнтованому вихованні, забезпеченні поваги до особистості кожного вихованця, довіри, співчуття, відсутності насилля, подоланні байдужості дорослих до проблем дітей тощо.

Для забезпечення гуманізації взаємин між дорослими і дітьми у всіх формах освітньої роботи інклюзивного закладу (групи) дошкільної освіти особливу увагу варто приділяти організації життєдіяльності дітей, де завдання виховання толерантного ставлення вирішується не лише на спеціальних заняттях, а є невід'ємною складовою усіх видів діяльності. Забезпечуючи цей напрям діяльності, доцільно керуватись думкою Т. Поніманської (2006, с. 17), проте, що виховання гуманних якостей особистості не може обмежуватись певними формами освітньої роботи чи місцем у режимі дня, тривалістю у часі. Дитина повинна здобувати соціальний досвід постійно, збагачуючи його гуманним змістом. Уся атмосфера закладу дошкільної освіти, поведінка дорослих, спілкування, спільна діяльність дітей - мають сприяти збагаченню досвіду гуманної поведінки дошкільнят.

Для забезпечення позитивного емоційного клімату в групі дітей, по-перше, необхідно виховувати доброзичливе ставлення один до одного, а також почуття емпатії. По-друге, розвивати власне уміння толерантного ставлення до однолітків, здійснювати пошук ефективних методів i прийомів їх формування. По-третє, створювати умови для закріплення умінь толерантного ставлення до однолітків та їх перенесення у різні ситуації спілкування.

Безсумнівно, що виховання толерантного ставлення до дітей 3 особливими освітніми потребами можливе лише за умови гуманного ставлення до партнерів зі спілкування та взаємодії, а головним завданням вихователя має бути виховання у дітей толерантного ставлення до довкілля, формування терпимості до особливостей i поведінки інших, розширення і поглиблення знань про добро, взаємодопомогу, справедливість, чесність, дружбу, співчуття.

На першому етапі роботи 3 дітьми необхідно прагнути розширити знання та уявлення дітей про доброзичливе, толерантне ставлення до інших. 3 цією метою доречно використовувати заняття типу: «Урок ввічливості», «Добрі почуття», «Лагідні слова», «Де живе добро?», «Справжній друг - хто він?», «Ти живеш серед людей», «Ми всі такі різні й неповторні», «Хлопчики й дівчатка - які вони?» та ін.

Особливу увагу на цих заняттях важливо звертати саме на вихованні у дітей толерантності, що виявляється у формуванні уявлень дітей про себе як унікальну, самоцінну та неповторну особистість; розвитку уявлень про інших людей на основі зіставлення себе з іншими, виокремлення подібних і відмінних рис; вихованні активної життєвої позиції; вихованні адекватного терпимого ставлення до дій та думок інших 
дітей.

Для формування власне умінь толерантного ставлення вкрай важливо використовувати ігри, спрямовані на розвиток комунікативних здібностей, на вміння розпізнавати й оцінювати емоційні стани інших дітей, на виховання позитивного ставлення до інших, на розвиток уміння співпереживати та на розвиток уміння співробітничати і взаємодіяти.

У ході проведення таких ігор для кожної дитини необхідно створювати атмосферу прийняття її іншими дітьми, що дозволить відчути стан успіху, зацікавленість інших дітей власною особистістю. Ігри, спрямовані на формування умінь та навичок толерантного ставлення до однолітків, виконують, заразом, і певну компенсаторну функцію. Так, відтворюючи позитивну гуманістичну забарвленість взаємин дітей із оточуючим світом, знижується загальна тривожність, запобігається виникнення страхів, що дозволяє кожній дитині, незалежно від її освітніх потреб, жити у злагоді 3 самою собою і оточуючими ії людьми.

Для постійної підтримки позитивного емоційного ставлення дітей один до одного ефективним $\epsilon$ і такий прийом, як розігрування уявних ситуацій: «Домовся із другом», «Що я відчуваю», «Розвесели друга» тощо.

Робота має бути зорієнтована на створення толерантного освітнього середовища до дітей з різними освітніми потребами, на створення сприятливого емоційного клімату взаємин дітей у групі. 3 цією метою в життя групи закладу дошкільної освіти варто запроваджувати різноманітні звичаї та традиції: наприклад, ранок радісних зустрічей (проводиться щодня, кожна дитина по черзі є «господарем» групи, до якої приходять друзі-однолітки. Спосіб привітання діти обирають самостійно. На дверях вивішується банер з відповідними позначками: рукостискання, обійми, посмішка, поцілунок, «дай п'ять»); сімейний сніданок, обід, вечеря; зустріч гостей; відвідини друзів; веселі вихідні тощо. Це, переконані, стане однією з найулюбленіших традицій.

Окрім зазначених вище напрямів роботи, необхідно визначити за мету навчити дітей переносити вміння толерантного ставлення до дітей з особливими потребами в різноманітні життєві ситуації: організовувати самостійні форм дорослих із дітьми, та дітей між собою, що забезпечить розширення досвіду спілкування. Це й буде ігрова діяльність, організація всіх видів праці в побуті, природі, художньої праці для прояву турботи та бережливого ставлення до соціального, предметного та природного оточення.

Наші спостереження засвідчують, що діти 3 особливими освітніми потребами досить часто відчувають проблеми в спілкуванні 3 іншими дітьми, перш за все, позбавлені адекватного вміння розмовляти, вести та підтримувати бесіду. У них виникають проблеми в тому, аби висловити свої бажання та емоції з словами, які вони переживають, що впливає і на їхню здатність розуміти емоційний стан та переживання інших. Тому організація спільної діяльності дозволяє їм позбутися цих проблем. Заразом, спільна діяльність позитивно впливає на звичайних дітей, а також сприяє запобіганню булінгу. Традиційно вважається, що проблема булінгу (залякування, цькування) ще не стосується дошкільної освіти, однак, як свідчить практика, вже серед дошкільників зустрічаються прояви задирання, знущання, висміювання, неприйняття дитини в групу, спільну діяльність через зовнішній вигляд, особливості розвитку тощо, а також такі прояви зустрічаються і з боку дорослих (вихователів та батьків). Саме тому виховання толерантного ставлення до людей необхідно розпочинати в дошкільному віці, аби в майбутньому запобігти таких негативних проявів поведінки у дітей в їхньому ставленні до інших, у тому числі й до дітей з особливими освітніми потребами.

Виокремлення певних етапів у вихованні толерантного ставлення до дітей 3 особливими потребами є досить умовним, оскільки на кожному етапі реалізовуються завдання й інших етапів. Не можна формувати навички толерантного ставлення без розуміння, що це також $\epsilon$, формуванням умінь, які необхідно закріплювати практично 
в різних ситуаціях взаємодії.

Висновки і перспективи подальших розвідок. Отже, одним з головних завдань дошкільної інклюзивної освіти є формування толерантного ставлення до дитини, незважаючи на особливості іiі психофізичного розвитку, яке можливе за умов гуманізації взаємин дорослих і дітей, а також створення сприятливого емоційного клімату в групі однолітків. Ефективність виховання толерантного ставлення забезпечується комплексним підходом: формування знань про толерантність, розвиток умінь толерантного ставлення до однолітків, закріплення умінь толерантного ставлення до однолітків та їх перенесення у різні ситуації спілкування.

Перспективи наступних розвідок вбачаємо в подальшому пошуку ефективних методів і прийомів виховання толерантного ставлення до дошкільників 3 особливими освітніми потребами.

\title{
СПИСОК ВИКОРИСТАНИХ ДЖЕРЕЛ
}

Міністерство науки і освіти, (2019). Інструктивно-методичні рекомендації «Щодо організації діяльності закладів освіти, що забезпечують здобуття дошкільної освіти y 2019/2020 навчальному рочі» [online]. Режим доступу: https://mon.gov.ua/ua/npa/shodo-organizaciyi-diyalnosti-zakladiv-osviti-sho-zabezpechuyutzdobuttya-doshkilnoyi-osviti-u-20192020-navchalnomu-roci

Рубинштейн, С. (2003). Бытие и сознание. Человек и мир. СПб., 508 с.

Поніманська, Т. (2006). Теоретико-методичні засади гуманістичного виховання дітей дошкільного віку. Рівне: РДГУ, 2006. 352 с.

\section{REFERENCES}

Ministerstvo nauky i osvity, (2019). Instruktyvno-metodychni rekomendatsii «Shchodo orhanizatsii diialnosti zakladiv osvity, shcho zabezpechuiut zdobuttia doshkilnoi osvity $u$ 2019/2020 navchalnomu rotsi» [Guidelines on the Organization of Activities of Educational Institutions Providing Pre-school Education in the 2019/2020 Academic Year]. [online]. Rezhym dostupu: https://mon.gov.ua/ua/npa/shodo-organizaciyi-diyalnosti-zakladiv-osvitisho-zabezpechuyut-zdobuttya-doshkilnoyi-osviti-u-20192020-navchalnomu-roci (in Ukrainian)

Rubinshteyn. S. (2003). Bytiye i soznaniye. Chelovek $i$ mir [Being and Consciousness. Human and the World]. SPb., 508 s. (in Russian)

Ponimanska, T. (2006). Teoretyko-metodychni zasady humanistychnoho vykhovannia ditei doshkilnoho viku [Theoretical and Methodological Principles of Humanistic Education of Preschool Children]. Rivne: RDHU, 2006. 352 s. (in Ukrainian).

\section{UPBRINGING OF TOLERANT ATTITUDE TOWARDS PRESCHOOLERS WITH SPECIAL EDUCATIONAL NEEDS}

\author{
Olha Kozliuk \\ Candidate of Pedagogical Sciences, Associate Professor, \\ Associate Professor at the Department of Pedagogy \\ and Psychology (Preschool and Correctional) \\ named after Professor T.Ponimanska, \\ Rivne State University for the Humanities, \\ Rivne, Ukraine \\ ORCID: 0000-0002-6948-327X \\ e-mail: olga_rdgu@ukr.net
}

\begin{abstract}
The article deals with the topicality of the tolerant attitude upbringing towards preschoolers with the special educational needs in the context of the inclusive education. It has been emphasized the need for the reassessment of the attitude and established stereotypes concerning a child with the special educational needs and the implementation of inclusive
\end{abstract}


values in the context of upbringing for sustainable development. The author assumes that the implementation of the inclusive education contributes to the socialization of both ordinary children and children with the special educational needs as well. Because it promotes the formation of tolerance for physical and mental disabilities of peers in healthy children, the formation of feelings of mutual assistance and desire for interaction; and for children with special needs cohabitation leads to the formation of the positive attitude towards their peers, adequate social behavior, better disclosure of potential development and training.

The peculiarities of the tolerant attitude forming towards children with the special needs in the conditions of the group inclusive preschool education have been defined through the implementation of the basic pedagogical conditions, in particular: humanization of relationships between adults and parents; creating of the positive emotional climate for the relationships of children in a team.

It has been emphasized the need for the integrated approach to the tolerant attitude upbringing: gaining of knowledge, development of the tolerant attitude to peers, consolidation of these skills, and their transfer to different communicative situations.

It has been defined prospects for further studying, related to the search for the effective methods and techniques for educating of children with the special educational needs.

Keywords: inclusion, inclusive values, tolerant attitude, upbringing of a tolerant attitude, preschoolers with special needs.

Стаття надійшла до редакиії 24.09.2019 p. 